\title{
Language Choice Used by EFL Teachers in Classroom Language during the Online Learning
}

\section{Faiz Rizaldi ${ }^{1}$}

\section{A R T I C L E I N F O}

Article history:

Received September 18, 2021

Revised September 20, 2021

Accepted November 17, 2021

Available online December 25, 2021

Kata Kunci:

Pilihan Bahasa, Ruang Belajar

Bahasa, Daring

Keywords:

Language Choice, Classroom

Language, EFL Teachers

DOI:

http://dx.doi.org/10.23887/jpbi.v9i3.43 816

\begin{abstract}
A B S T R A K
Perpindahan kelas konvensional menjadi kelas online cenderung memunculkan tantangan baru bagi guru bahasa Inggris khususnya dalam konteks EFL. Penelitian ini bertujuan untuk menemukan pilihan bahasa yang digunakan dalam menyediakan ruang belajar bahasa Inggris selama pembelajaran daring. Desain penelitian kualitatif digunakan dalam penelitian ini. Data dikumpulkan melalui observasi dan interview dengan menggunakan table-check-list, interview guide, dan table klasifikasi dimana seorang guru bahasa Inggris yang mengajar siswa kelas 8 dilibatkan sebagai subyek penelitian. Obyek penelitian yaitu pilihan bahasa yang digunakan oleh pengajar bahasa Inggris dalam ruang belajar bahasa selama pembelajaran online. Analisis data interaktif digunakan selama proses menganalisis data. Hasil penelitian menunjukkan bahwa terdapat tiga pilihan bahasa yang digunakan yakni; bahasa Inggris sebagai bahasa target, bahasa Indonesia sebagai bahasa ibu dari siswa, dan campuran antara bahasa Indonesia dan Inggris. Ditemukan bahwa bahasa Inggris adalah pilihan bahasa yang paling sering digunakan oleh guru dan siswa ketika mereka melakukan aktivitas dan berkomunikasi saat proses pembelajaran dengan ditunjukkan oleh presentase penggunaannya di skala 4 (61-80\%) dan 5 (81-100\%). Sedangkan bahasa Indonesia juga digunakan namun dalam tingkat sedang ditunjukkan pada presentase $2(21-40 \%)$ dan 3 (41-60\%). Bahasa campuran antara Indonesia dan Inggris merupakan bahasa yang paling jarang digunakan mengingat bahwa hal ini ditunjukkan dengan presentase 1 (0-20\%). Disisi lain, guru juga mengharuskan siswa menggunakan bahasa Inggris selama sesi diskusi untuk meningkatkan pengalaman mereka dalam menggunakan bahasa Inggris.
\end{abstract}

\section{A B S T R A C T}

Penerapan pembelajaran online akibat Covid-19 telah menjadi fenomena yang banyak diperbincangkan di dunia pendidikan khususnya dalam proses belajar mengajar bahasa Inggris. Pembelajaran online diterapkan di sekolah masih terdapat kesulitan yang dihadapi oleh guru dan siswa baik secara teknis maupun nonteknis. Evaluasi terhadap pembelajaran online jarang dilakukan, sehingga belum ditemukan solusi yang signifikan untuk mengatasi kesulitan dalam melakukan pembelajaran online. Penelitian ini bertujuan untuk menganalisis persepsi guru EFL terhadap pembelajaran online selama pandemi Covid-19 dengan berfokus pada evaluasi aspek konteks pembelajaran. Metode kualitatif digunakan sebagai desain penelitian dengan mengadaptasi Model CIPPO. Data dikumpulkan melalui beberapa teknik, seperti; observasi, dokumentasi, administrasi angket, dan wawancara. Data yang diperoleh dianalisis secara deskriptif kuantitatif. Hasil penelitian menunjukkan bahwa pelaksanaan pembelajaran online pada masa pandemi covid-19 sudah efektif dan berjalan dengan baik. Namun, guru harus meningkatkan keterampilan mengajar mereka, terutama selama pembelajaran online, untuk membuat siswa bersemangat untuk belajar, terutama dalam belajar bahasa Inggris. Selain itu, guru harus membuat media pembelajaran yang menarik, atau merancang materi pembelajaran yang kreatif untuk menarik perhatian siswa. Di sisi lain, peran keterlibatan orang tua juga penting dalam bidang ini. Hal ini dikarenakan siswa lebih banyak menghabiskan waktunya di rumah. Oleh karena itu, orang tua harus mendukung penuh anak-anaknya, seperti menyediakan smartphone yang sesuai untuk kelas belajar online mereka, juga kouta internet.

This is an open-access article under the CC BY-SA license. Copyright (C) 2021 by Author. Published by Universitas Pendidikan Ganesha.

\section{INTRODUCTION}

English has been recognized as the most vital foreign language that is learned among other language speakers around the world (Basri, 2018; Escobar Fandiño et al., 2019; Mokshein et al., 2019). It is relevant to the recent phenomenon which shows that English placed as the fourth rank of foreign language mostly spoken by people as an international communication (Cao \& Wei, 2019; Hien, 2021; Setyowati \& Sukmawan, 2016). States the global use of English appears as a phenomenon since it impacts all the sectors of humans' life, such as; social and cultural sectors, business, and education (Bećirović, 2017; Smith et al., 2018; Zein et al., 2018). Despite, its influences on humans' life, English is also perceived as a requirement for being a successful individual in the globalization era. It demands stakeholders and the government to input English as one of the compulsory subjects 
required to be learnt by the students (Ho, 2020; Liu \& Song, 2021; Tanihardjo, 2016). Students are supposed to learn and master English as a means of communication considering that English can increase students' competencies both in academic and social life (Prastyo et al., 2021; Swanson, 2020). It is stated that learning English is referred to the process of updating information and required material that influences citizens' ability that reflects their literacy and open-mindedness. Therefore, the importance of English has been realized by a lot of people including Indonesian people which is reflected through the Indonesian educational curricula that attach English to government policy (Friantary \& Martina, 2018; Hery, 2017; Rosmiati, 2019).

However, English language teaching and learning has faced a rapid change due to the Covid-19 pandemic that almost occurs in all the countries including Indonesia (Agung et al., 2020; Ambarita, 2021; Hidayati \& Husna, 2020). The Covid-19 pandemic has greatly impacted the education system where institutions are closed for the prevention of the Covid-19 virus (Huang, 2020; Hussein et al., 2020; Oyedotun, 2020). The new learning system is adapted where the conventional learning is changed into online learning which means that a direct formal knowledge cannot be conducted instead virtual classrooms are taken as the solution (Khatoony \& Nezhadmehr, 2020; Mishra et al., 2020; Yunita \& Maisarah, 2020). Online learning is an advance of technology that is perceived as innovation in education where it supports the learning process to be more efficient and flexible (Meşe \& Sevilen, 2021; Mutohhari et al., 2021; Sukendro et al., 2020). The interaction between teachers and students occurs asynchronously and synchronously where the teachers can communicate and interact with their students synchronously by using virtual media, such as; Zoom, Google Meet, WebEx, and others meanwhile asynchronous learning is conducted through the use of WhatsApp, YouTube, Google Classroom, Schoology, and other learning platforms (Lapitan et al., 2021; Rachmat \& Krisnadi, 2020; Susilowati, 2020).

The transmission of the conventional classrooms into online classroom tends to emerge as a new challenge for the English teachers, particularly in the EFL context as what has been found by the researchers through a preliminary observation conducted in SMP N 2 Gerokgak. It is one of the junior high schools in Buleleng regency which adapts online learning during the Covid-19 pandemic. It is found that the English teachers use monotonous media, such as; WhatsApp and Google Classroom. The lack of facilities owned by students does not support the learning process to be conducted through the virtual live meeting. Indirectly, it also impacts the class language that cannot be running optimally. Most of the teachers use a mixture of languages between Bahasa and English. The teachers tend to switch languages. It occurs to the teachers who are not ready enough in facing the new learning system and overcoming students' characteristics considering that students still have difficulty in understanding the learning process if the language used is fully in English. It is noticed that teachers mostly interact with students by only giving assignments as an exercise for students, that conditions are contradictory to the purpose of classroom language which is for familiarizing students with the target language. There is less interaction and communication conducted by teachers by using the language target.

A recent study about classroom language has been conducted in which it is more focused on investigating the perceptions of senior high school students towards the classroom language used in learning English as a foreign language (Effendi M., 2016; Megawati, 2016; Sibarani, 2019). The students' perceptions towards the use of Indonesian and English in the learning process. It shows that students mostly prefer the use of Indonesian in English language learning which indicates a negative side for the English learning process considering that English is required as the primary language in EFL classrooms. The language choice used between university students and their lecturers in the classroom interaction in which it is found that English is less used than Bahasa during the English course (Julianti et al., 2016; Liyana \& Kurniawan, 2019; Ratminingsih, 2018). English is used by the lecturers for asking students' thoughts and feelings, asking the question, and praising meanwhile students use English only for responding to a specific category. Bahasa is mostly used by students to give their ideas and information, bring a joke, and criticize other students' behavior. The language choice is used by English teachers in EFL classrooms in their talks and interactions with students (Pratiwi, 2019). It is also found that Bahasa is commonly used by teachers for translating difficult words found in English and explaining grammar. Inserting mother tongue is viewed as a limitation for students to expose their target language. Therefore, the language choice used by the teachers in that study shows a negative response.

Those previous studies show that the language choices and classroom language in the EFL context have attracted many researchers in which most of the studies reveal that the use of Bahasa as students' mother tongue is more dominant than English as their target language. Those studies are conducted when the learning process is conducted conventionally. There is no recent study that investigates the language choice used by English teachers for conducting classroom language in teaching English as a foreign language during online learning. Therefore, this study is conducted to analyze the language choice used by teachers in conducting classroom language during the online learning considering it is a sudden change in the Indonesian learning system and the importance of using English in implementing classroom language in which this study is underlined by the research question; what language choice of classroom language is used by EFL teachers in SMPN 2 Gerokgak. 


\section{METHOD}

This study was conducted in the form of a qualitative study. Creswell (2008) states that qualitative research is a research method used to observe and understand the central phenomenon by involving the participants or volunteers and asking those general questions broadly. The setting of this study was SMPN 2 Gerokgak in which the English teachers were involved as the subject of this study. The language choice used by the English teachers in conducting classroom language during online learning became the object of this study. The data were gained through observation and interview by using a table checklist, interview guide, and classification table. Data analysis was carried out using Interactive Model Analysis which included three main processes, namely; data reduction, data display, and leverage (Miles \& Huberman, 1994). The validity and reliability of this study were checked through data triangulation.

\section{RESULT AND DISCUSSION}

\section{Result}

Observation of the English teaching and learning process in SMP N 2 Gerokgak by obtaining 10 EFL learning meetings for $8^{\text {th }}$-grade students. $8 \mathrm{~A} 1$ is the selected class to be observed by the researcher through the use of a table checklist. In addition, the interview was also conducted involving one English teacher who taught English as a foreign language in that class. There were five scales of percentage used as references; 1) 0-20\%, 2) 21-40\%, 3) $41-60 \%$, 4) $61-80 \%, 5) 81-100 \%$. The table checklist consisted of three indicators based on the theory proposed by Kang (2008). The finding of this study was presented in Table 1.

Table 1. The Distribution of Language Choice Used in Implementing Classroom Language during the Online Learning

\begin{tabular}{|c|c|c|}
\hline Meeting 1 & $\begin{array}{c}\text { Number of Phrases or } \\
\text { Sentences Used }\end{array}$ & $\begin{array}{c}\text { Frequency of } \\
\text { Occurrences }(\%)\end{array}$ \\
\hline L1 (Bahasa) & 7 & $50 \%$ \\
\hline L2 (English) & 7 & $50 \%$ \\
\hline Mixture of L1 and L2 & 0 & $0 \%$ \\
\hline \multicolumn{3}{|l|}{ Meeting 2} \\
\hline L1 (Bahasa) & 5 & $13.51 \%$ \\
\hline L2 (English) & 31 & $83.78 \%$ \\
\hline Mixture of L1 and L2 & 1 & $2.71 \%$ \\
\hline \multicolumn{3}{|l|}{ Meeting 3} \\
\hline L1 (Bahasa) & 4 & $20 \%$ \\
\hline L2 (English) & 14 & $70 \%$ \\
\hline Mixture of L1 and L2 & 2 & $10 \%$ \\
\hline \multicolumn{3}{|l|}{ Meeting 4} \\
\hline L1 (Bahasa) & 7 & $31.82 \%$ \\
\hline L2 (English) & 13 & $59.09 \%$ \\
\hline Mixture of L1 and L2 & 2 & $9.09 \%$ \\
\hline \multicolumn{3}{|l|}{ Meeting 5} \\
\hline L1 (Bahasa) & 75 & $22.73 \%$ \\
\hline L2 (English) & 16 & $72.73 \%$ \\
\hline Mixture of L1 and L2 & 1 & $4.54 \%$ \\
\hline \multicolumn{3}{|l|}{ Meeting 6} \\
\hline L1 (Bahasa) & 9 & $47.37 \%$ \\
\hline L2 (English) & 9 & $47.37 \%$ \\
\hline Mixture of L1 and L2 & 1 & $5.26 \%$ \\
\hline \multicolumn{3}{|l|}{ Meeting 7} \\
\hline L1 (Bahasa) & 2 & $25 \%$ \\
\hline L2 (English) & 6 & $75 \%$ \\
\hline Mixture of L1 and L2 & 0 & $0 \%$ \\
\hline \multicolumn{3}{|l|}{ Meeting 8} \\
\hline L1 (Bahasa) & 13 & $26 \%$ \\
\hline L2 (English) & 30 & $60 \%$ \\
\hline Mixture of L1 and L2 & 7 & $14 \%$ \\
\hline \multicolumn{3}{|l|}{ Meeting 9} \\
\hline L1 (Bahasa) & 7 & $19.45 \%$ \\
\hline
\end{tabular}




\begin{tabular}{lcc}
\hline Meeting 1 & $\begin{array}{c}\text { Number of Phrases or } \\
\text { Sentences Used }\end{array}$ & $\begin{array}{c}\text { Frequency of } \\
\text { Occurrences }(\%)\end{array}$ \\
\hline L2 (English) & 27 & $75 \%$ \\
Mixture of L1 and L2 & 2 & $5.55 \%$ \\
Meeting 10 & & \\
L1 (Bahasa) & 12 & $46.15 \%$ \\
L2 (English) & 11 & $42.31 \%$ \\
Mixture of L1 and L2 & 3 & $11.54 \%$ \\
\hline
\end{tabular}

Table 1 showed the language choice of classroom language used by the teachers in interacting with the students during the English class conducted through online learning. It was found that English was dominantly used by the teacher in those ten meetings considering that the use of L2 (English) mostly reached the percentage of 4 in each meeting which was around $60-80 \%$ meanwhile it was also presented that English was used on the percentage of $3(41-60 \%)$ in the meeting 1, 4, 6, and 10. The most significant use of English was found in meeting 2 which reached the percentage of $5(83.78 \%)$. Bahasa as students' native language (L1) was also used by the teacher during the teaching and learning process but it was used less than L 2 which showed that the use of Bahasa typically reached the percentage of $1(0-20 \%)$ and 2 (21-40\%) in each meeting. In addition, the mixture between L1 and L2 was the least frequent language used by the teacher in the learning activities considering that it was presented on the percentage of $1(0-20 \%)$. The table checklist indicated that English was positioned as the dominant language used by the teacher while teaching English as a foreign language for $8^{\text {th }}$-grade students in SMPN 2 Gerokgak. English was often used for all the classroom activities, such as; greeting, giving instructions, discussions, and providing feedback to students. Teacher commonly used a simple phrase or sentence to make students understand the instructions easily, for instance; "hello students", "how are you?", "please fill the absent", "read the dialogue, please!". Meanwhile, complex English was used during discussion sessions and giving feedback.

\section{Discussion}

As an educator who has an important role in the teaching and learning process, English teachers have a responsibility in balancing the classroom interaction by using classroom language while teaching English as a foreign language (Hanifa, 2018; Luciana, 2020; Nugroho \& Mutiaraningrum, 2020). Classroom language is a common way used by English teachers to motivate students to actively participate in the classroom where the teachers are supposed to use an appropriate language that enables students for being involved in the classrooms (Figueras-Daniel \& Li, 2021; Meng \& Wang, 2011; Moghadam et al., 2021). In the EFL context, the teachers must use English in conducting classroom language since English becomes a target language but it contrasts to students' mother tongue (native language), particularly for the early students. It is stated that the contrast between the target language and students' mother tongue leads the teachers to apply a good classroom language by habituating the use of target language for the students from an early age (Cekaite, 2017; Saito et al., 2018; Singh et al., 2020). English has been officially regulated to be taught in primary schools and secondary schools by the Indonesian government (Sibarani, 2019). English learning process in Indonesia has been stated through Government Regulation, No. 19, 2005, that demands the final goal of English learning process is students' participation in discoursing or communicating their feelings, ideas thought, whether it is presented in verbal or non-verbal English inaccurate, fluent, and acceptable ways (Yulia, 2013).

The result indicated that the language choice used by the teacher in implementing classroom language for teaching EFL during the online learning consisted of three variant languages; exclusive of the target language (L2), exclusive of students' native language (L1), and the mixture of L1 and L2. It was supported by the result of the interview elaborated as follows; First, exclusive of the target language (TL). English had been found as the dominant language used in EFL learning class in 8A1 at SMPN 2 Gerokgak. English was not used by the teacher but also by the students who were required to use English in the discussion sessions by the teacher (Bella \& Zainil, 2020; Kamelia, 2019; Tovar Viera et al., 2020). It was underlined by a reason of the teacher who wanted to provoke students' experience in using English as what had been stated through the teacher's interview statement, as follows.

"The use of English and Indonesian in learning for junior high school students is 50 to 50. I do this because I want my students to get used to using English in my classroom. Therefore, I often ask students to answer my questions or argue in my class using English. I want them to learn English meaningfully."

Second, Exclusive of the first language (L1). Bahasa was used by the teacher to re-explain what had been delivered in English by her in the previous sessions (Albashtawi et al., 2020; Alshenqeeti, 2018). It was conducted due to the inequality of students' knowledge. Teachers commonly translated several English words into Bahasa to increase students' understanding of the instructions and learning materials as what had been stated in the statement below; 
"I also often use Indonesian in my English class. I do that because I want students to understand what I say besides I want students to use English in my class. Besides that, there is an inequality of knowledge in my class, so I want all students to understand what I am saying."

Third, The Mixed-Use of L1 and L2. Teachers tend to use mixed language between Bahasa and English spontaneously for explaining or mentioning the words that only had popular meaning in Bahasa or English (Dwihartanti \& Faizah, 2018; Trisnanti et al., 2018; Widyahening, 2018). The teacher used English first and it was followed by Bahasa. The mixed language was infrequently used by the teacher to make students have a better understanding.

"If we talk about mixed languages, it might happen. The language is more popular than English when I speak Indonesian and vice versa. I just did it spontaneously because it was intended to make students understand the learning in my class better."

Based on those findings, it could be interpreted that there were three variations of language choice used for classroom language in the EFL learning process joined by $8^{\text {th }}$-grade students at SMPN 2 Gerokgak, such as; exclusive target language (L2), exclusive students' first language (L1), and a mixture of L1 and L2. It was relevant to find that classroom language was implemented by using three variants of language choice during the English teaching and learning process, such as; English, Bahasa, and a mix of several languages. It was also found that English was the dominant language that should be used in classroom language (Saraswati et al., 2020; Sya \& Helmanto, 2020; Yulia, 2013). It was in line with the result of this study where English was the most frequent language used by the teacher. The result of this study was in contrast to the previous studies in which those studies showed that Bahasa was frequently used in classroom language by the students to elaborate and present their ideas, thoughts, and feeling meanwhile this study pointed out that the students were obligated to use English in discussion sessions and teacher used English dominantly (Julianti et al., 2016; Pratiwi, 2019). A more complex study is suggested to be conducted which focuses on investigating the language choice used in classroom language during online learning by using the result of this study as reference. This result is feedback towards the undertaken of online learning as a new learning system for junior high school students in Buleleng in which it can be used as a reference for the English teachers in conducting classroom language for teaching English as a foreign language.

\section{CONCLUSION}

The classroom language was managed well by the EFL teacher at SMPN 2 Gerokgak in teaching English for $8^{\text {th }}$-grade students during the online learning where there were three variants of language choice used such as; English as the target language, Bahasa as students' first language, and a mixed language between Bahasa and English. It was found that English was dominantly used by the teacher during the English online learning process in 10 meetings. It was shown on the percentage of 4 (60-180\%) and 5 (81-100\%). Meanwhile, the use of Bahasa was intermediate on the percentage of $3(40-60 \%)$. The least use was the mixed language considering it reached the percentage of $1(0-20 \%)$. It was also found that the teacher obligated the students to use English during the discussion sessions for exploring students' experience in using English.

\section{REFERENCES}

Agung, A. S. S. N., Surtikanti, M. W., \& Quinones, C. A. (2020). Students' Perception o f Online Learning during COVID-19 Pandemic: A Case Study on the English Students of STKIP Pamane Talino. Jurnal Sosial Dan Humaniora, 10(2), 225-235. https://doi.org/10.31940/soshum.v10i2.1316.

Albashtawi, A., Ham Albashtawi, A. H., \& Bataineh, A. (2020). The effectiveness of google classroom among EFL students in Jordan: An innovative teaching and learning online platform. International Journal of Emerging Technologies in Learning, 15(11), 78-88. https://doi.org/10.3991/IJET.V15I11.12865.

Alshenqeeti, H. (2018). Motivation and Foreign Language Learning: Exploring the Rise of Motivation Strategies in the EFL Classroom. International Journal of Applied Linguistics and English Literature, 7(7), 1. https://doi.org/10.7575/aiac.ijalel.v.7n.7p.1.

Ambarita, E. (2021). Belajar Dari Rumah (Bdr) Menggunakan Padlet Alternatif E-Learning Pada Masa Pandemi Covid-19 (Studi Kasus Di Sman 56 Jakarta). JIRA: Jurnal Inovasi Dan Riset Akademik, 2(1), 30-36. https://doi.org/10.47387/jira.v2i1.70.

Basri, H. (2018). Strategi Belajar Kosakata Bahasa Inggris (English Vocabulary). Strategi Belajar Kosakata Bahasa Inggris (English Vocabulary, 11(2), 432-444. https://doi.org/10.19105/ojbs.v8i2.468. 
Bećirović, S. (2017). The relationship between gender, motivation, and achievement in learning English as a foreign language. European Journal of Contemporary Education, 6(2), 210-220. https://doi.org/10.13187/ejced.2017.2.210.

Bella, M. S., \& Zainil, Y. (2020). An Analysis of Teachers' classroom Language at SMPN 4 Muara Bungo. Journal of English Language Teaching, 9(4), 644-651. https://doi.org/10.24036/jelt.v9i4.110200.

Cao, Y. K., \& Wei, W. (2019). Willingness to communicate from an English as an International Language (EIL) perspective: The case of Macau. System, 87. https://doi.org/10.1016/j.system.2019.102149.

Cekaite, A. (2017). What Makes a Child a Good Language Learner? Interactional Competence, Identity, and Immersion in a Swedish Classroom. Annual Review of Applied Linguistics, 37, 45-61. https://doi.org/10.1017/S0267190517000046.

Dwihartanti, M., \& Faizah, N. N. (2018). Pentingnya Penguasaan Bahasa Inggris Bagi Pelaksanaan Tugas Rutin Sekretaris. Efisiensi - Kajian Ilmu Administrasi, 15(1). https://doi.org/10.21831/efisiensi.v15i1.24483.

Effendi M. (2016). Penerapan Lesson Study dalam Meningkatkan Kemampuan Mengajar Guru Bahasa Inggris pada Madrasah Tsanawiyah Negeri Model Sorong. Journal of Islamic Education, 1(2). https://doi.org/10.30984/j.v1i2.430.

Escobar Fandiño, F. G., Muñoz, L. D., \& Silva Velandia, A. J. (2019). Motivation and E-Learning English as a foreign language: A qualitative study. Heliyon, 5(9). https://doi.org/10.1016/j.heliyon.2019.e02394.

Figueras-Daniel, A., \& Li, Z. (2021). Evidence of support for dual language learners in a study of bilingual staffing patterns using the Classroom Assessment of Supports for Emergent Bilingual Acquisition (CASEBA). Early Childhood Research Quarterly, 54. https://doi.org/10.1016/j.ecresq.2020.09.011.

Friantary, H., \& Martina, F. (2018). Evaluasi Implementasi Penilaian Hasil Belajar Berdasarkan Kurikulum 2013 oleh Guru Bahasa Inggris dan Bahasa Indonesia di MTS Ja-Alhaq Kota Bengkulu. Silampari Bisa: Jurnal Penelitian Pendidikan Bahasa Indonesia, Daerah, Dan Asing, 1(2), 76-95. https://doi.org/10.31540/silamparibisa.v1i2.202.

Hanifa, R. (2018). EFL Published Materials: An Evaluation of English Textbooks for Junior High School in Indonesia. Advances in Language and Literary Studies, 9(2), 166. https://doi.org/10.7575/aiac.alls.v.9n.2p.166.

Hery, Y. (2017). Teachers and students perceptions of communicative competence in English as a foreign language in Indonesia. Educational Research and Reviews, 12(17), 867-883. https://doi.org/10.5897/err2017.3243.

Hidayati, T., \& Husna, F. (2020). Learning English from Home during the Covid-19: Investigating Learners ' Experience for Online and Autonomous Learning. Journal of The Association for Arabic and English, 6(2), 202-217. https://doi.org/10.313 32/lkw.v6i2.1962.

Hien, L. T. N. (2021). Communicative Language Teaching in Teaching ESL for University Students. Journal of English Language Teaching and Applied Linguistics, 3(6), 49-57. https://doi.org/10.32996/jeltal.2021.3.6.7.

Ho, Y.-Y. C. (2020). Communicative language teaching and English as a foreign language undergraduates' communicative competence in Tourism English. Journal of Hospitality, Leisure, Sport \& Tourism Education, 27. https://doi.org/10.1016/j.jhlste.2020.100271.

Huang, Y. (2020). Research on Online Education in the Midst of the COVID-19 Pandemic. Journal of Advances in Education Research, 5(2), 125-137. https://doi.org/10.22606/jaer.2020.52005.

Hussein, E., Daoud, S., Alrabaiah, H., \& Badawi, R. (2020). Exploring undergraduate students' attitudes towards emergency online learning during COVID-19: A case from the UAE. Children and Youth Services Review, 119(10), 105699. https://doi.org/10.1016/j.childyouth.2020.105699.

Julianti, R., Atmowardoyo, H., \& Mahmud, M. (2016). University English Teachers and Students' Perceptions of Language Choices in EFL Classroom. ELT Worldwide: Journal of English Language Teaching, 3(2), 204. https://doi.org/10.26858/eltww.v3i2.2258.

Kamelia, K. (2019). Using Video as Media of Teaching in English Language Classroom: Expressing Congratulation and Hopes. Utamax: Journal of Ultimate Research and Trends in Education, 1(1), 34-38. https://doi.org/10.31849/utamax.v1i1.2742.

Khatoony, S., \& Nezhadmehr, M. (2020). EFL teachers' challenges in integration of technology for online classrooms during Coronavirus (COVID-19) pandemic in Iran. AJELP: Asian Journal of English Language and Pedagogy, 8(2), 1-16. https://doi.org/10.37134/ajelp.vol8.sp.1.2020.

Lapitan, L. D., Tiangco, C. E., Sumalinog, D. A. G., Sabarillo, N. S., \& Diaz, J. M. (2021). An effective blended online teaching and learning strategy during the COVID-19 pandemic. Education for Chemical Engineers, 35(May 2020), 116-131. https://doi.org/10.1016/j.ece.2021.01.012. 
Liu, H., \& Song, X. (2021). Exploring “Flow” in young Chinese EFL learners' online English learning activities. System, 91. https://doi.org/10.1016/j.system.2020.102425.

Liyana, A., \& Kurniawan, M. (2019). Speaking Pyramid sebagai Media Pembelajaran Kosa Kata Bahasa Inggris Anak Usia 5-6 Tahun. Jurnal Obsesi : Journal of Early Childhood Education, 3(1). https://doi.org/10.31004/obsesi.v3i1.178.

Luciana, N. L. R. (2020). Teachers' Readiness in Inserting the 21 st Century Skills in the Lesson Plan in Teaching English. Jurnal Pendidikan Dan Pengajaran, 53(2), 168. https://doi.org/10.23887/jpp.v53i2.26406.

Megawati. (2016). Kesulitan Mahasiswa Dalam Mencapai Pembelajaran Bahasa Inggris Secara Efektif. Jurnal Pedagogia, 5(2). https://doi.org/10.21070/pedagogia.v5i2.246.

Meng, X., \& Wang, X. (2011). Action study of teacher's language on EFL classroom interaction. Theory and Practice in Language Studies, 1(1), 98-104. https://doi.org/10.4304/tpls.1.1.98-104.

Meşe, E., \& Sevilen, Ç. (2021). Factors influencing EFL students' motivation in online learning: A qualitative case study. Journal of Educational Technology \& Online Learning, 4(1), 11-22. https://doi.org/10.31681/ jetol.817680.

Miles, M. B., \& Huberman, A. M. (1994). Qualitative Data Analysis (Second Edi). Sage Publication.

Mishra, L., Gupta, T., \& Shree, A. (2020). Online teaching-learning in higher education during lockdown period of COVID-19 pandemic. International Journal of Educational Research Open, 1, 100012. https://doi.org/10.1016/j.ijedro.2020.100012.

Moghadam, Z. B., Narafshan, M. H., \& Tajadini, M. (2021). Development of a Critical Self in the Language Reading Classroom: An examination of Learners' L2 Self. Thinking Skills and Creativity, 3. https://doi.org/10.1016/j.tsc.2021.100944.

Mokshein, S. E., Ishak, H., \& Ahmad, H. (2019). the Use of Rasch Measurement Model in English Testing. Jurnal Cakrawala Pendidikan, 38(1), 16-32. https://doi.org/10.21831/cp.v38i1.22750.

Mutohhari, F., Sudira, P., \& Nurtanto, M. (2021). Automotive Engineering Drawing Learning: Effective Online Learning Using Autocad Application. Journal of Education Technology, 5(2), 214-219. https://doi.org/10.23887/jet.v5i2.33197.

Nugroho, A., \& Mutiaraningrum, I. (2020). EFL teachers' beliefs and practices about digital learning of English. EduLite Journal of English Education, Literature, and Culture, 5(2), 304-321. https://doi.org/10.30659/e.5.2.304-321.

Oyedotun, T. D. (2020). Sudden change of pedagogy in education driven by COVID-19: Perspectives and evaluation from a developing country. Research in Globalization, 2(June), 100029. https://doi.org/10.1016/j.resglo.2020.100029.

Prastyo, Y. D., Silviyani, \& Dharmawan, Y. Y. (2021). The Effect of Board Games on Students' Communicative Competence. Beyond Linguistika: Journal of Linguistics and Language Education, 4(2), 33. https://doi.org/10.36448/bl.v4i2.2279.

Pratiwi, W. R. (2019). Teacher Talk and Instructional Language Choice: Two Problems Encountered in Efl Classroom. ETERNAL (English, Teaching, Learning, and Research Journal), 5(1), 195. https://doi.org/10.24252/eternal.v51.2019.a15.

Rachmat, A., \& Krisnadi, I. (2020). Analisis Efektifitas Pembelajaran Daring (Online) Untuk Siswa SMK Negeri 8 Kota Tangerang Pada Saat Pandemi Covid 19. Jurnal Pendidikan, 1(1), 1-7.

Ratminingsih, N. M. (2018). Implementasi Board Games Dan Pengaruhnya Terhadap Hasil Belajar Bahasa Inggris. Jurnal Ilmu Pendidikan, 24(1), 19. https://doi.org/10.17977/um048v24i1p19-28.

Rosmiati, M. (2019). Animasi Interaktif Sebagai Media Pembelajaran Bahasa Inggris Menggunakan Metode ADDIE. Paradigma: Jurnal Komputer Dan Informatika Univiersitas Bina Sarana Informatika, 21(2). https://doi.org/10.31294/p.v21i2.6019.

Saito, K., Dewaele, J.-M., Abe, M., \& In'nami, Y. (2018). Motivation, Emotion, Learning Experience, and Second Language Comprehensibility Development in Classroom Settings: A Cross-Sectional and Longitudinal Study. Language Learning, 68(3), 709-743. https://doi.org/10.1111/lang.12297.

Saraswati, W., Budiman, M. A., \& Rahmawati, I. (2020). Pembelajaran Bahasa Inggris Di SD Negeri Petompon 01 Semarang. Jurnal Sekolah, 4(4). https://doi.org/10.24114/js.v4i4.20616.

Setyowati, L., \& Sukmawan, S. (2016). EFL Indonesian Students' Attitude toward Writing in English. Arab World English Journal (AWEJ), 7(4). https://doi.org/10.24093/awej/vol7no4.24.

Sibarani, C. (2019). Students Perceptions of Teachers Use of Bahasa Indonesia in the English Classroom. JET (Journal of English Teaching), 5(3), 217. https://doi.org/10.33541/jet.v5i3.1315.

Singh, C. K. S., Singh, T. S. M., Abdullah, N. Y., Moneyam, S., Ismail, M. R., Tek, E., Karupayah, T., Chenderan, K., Singh, M. K. R., \& Singh, J. K. S. (2020). Rethinking English language teaching through Telegram, Whatsapp, Google classroom, and Zoom. Systematic Reviews in Pharmacy, 11(11), 45-54. https://doi.org/10.31838/srp.2020.11.9. 
Smith, P., Warrican, S. J., Kumi-Yeboah, A., \& Richards, J. (2018). Understanding Afro-Caribbean educators' experiences with Englishes across Caribbean and U.S. contexts and classrooms: Recursivity, (re)positionality, bidirectionality. Teaching and Teacher Education, 69. https://doi.org/10.1016/j.tate.2017.10.009.

Sukendro, S., Habibi, A., Khaeruddin, K., Indrayana, B., Syahruddin, S., Makadada, F. A., \& Hakim, H. (2020). Using an extended Technology Acceptance Model to understand students' use of e-learning during Covid-19: Indonesian sport science education context. Heliyon, 6(11), e05410. https://doi.org/10.1016/j.heliyon.2020.e05410.

Susilowati, E. (2020). Bagaimana Pembelajaran Daring di Tengah Wabah Covid 19 melalui Grup WhatsApp? Jurnal Pendidikan Matematika Raflesia, 05(03), 1-25. https://doi.org/10.33449/jpmr.v5i3.12896.

Swanson, H. L. (2020). The relationship between executive processing and computational growth among monolingual and English learners with and without math difficulties: Does it help to be bilingual? Cognitive Development, 56. https://doi.org/10.1016/j.cogdev.2020.100961.

Sya, M. F., \& Helmanto, F. (2020). Pemerataan Pembelajaran Muatan Lokal Bahasa Inggris Sekolah Dasar Indonesia. Jurnal Pendidikan Guru Sekolah Dasar, 7(1). https://doi.org/10.30997/dt.v7i1.2348.

Tanihardjo, J. (2016). The Analysis of Students' English Competence in the Grammar Section in the PaperBased TOEFL: A Case Study at English Department in Bunda Mulia University. Journal of English Language \& Culture, 6(1). https://doi.org/10.30813/jelc.v6i1.270.

Tovar Viera, R., Velasco Sánchez, Diego IsmaelTovar Viera, R., \& Velasco Sánchez, D. I. (2020). Research on Technology Competencies in EFL Language Instructors: Technology-Pedagogy-Content in Language Teaching. Script Journal: Journal of Linguistics and English Teaching, 5(1), 32-43. https://doi.org/10.24903/sj.v5i1.414.

Trisnanti, I. A. N. L., Tirtayani, L. A., \& Putra, I. K. A. (2018). Pengaruh Media Flashcard Bilingual Terhadap Kemampuan Kosakata Bahasa Inggris Permulaan Anak Kelompok B TK Gugus Mawa. Journal Pendidikan Anak Usia Dini Undiksha, 6(3), 346. https://doi.org/10.23887/paud.v6i1.15200.

Widyahening, E. T. (2018). Penggunaan Classroom Language Dalam Pembelajaran Bahasa Inggris Bagi Guru Sdn 01 Suruh Tasikmadu Karanganyar. ADIWIDYA, II(2), 159-166. https://doi.org/10.33061/awpm.v2i2.2518.

Yulia, Y. (2013). Teaching Challenges In Indonesia: Motivating Students And Teachers ' Classroom Language Tantangan Pengajaran Di Indonesia. Indonesian Journal of Applied Linguistics, 3(1). https://doi.org/10.17509/ijal.v3i1.186.

Yunita, W., \& Maisarah, I. (2020). Students ' Perception On Learning Language At The Graduate Program OF English Education Amids The Covid 19 Pandemic. Linguists: Journal of Linguistics and Language Teaching, 2069(6), 107-120. https://doi.org/10.29300/ling.v6i2.3718.

Zein, T. T., Sinar, T. S., Nurlela, N., \& Yusuf, M. (2018). Process Types of Transitivity System in English Department Students' Narrative Texts. Atlantis Press, 276. https://doi.org/10.2991/icoelt18.2019.21. 